\title{
Antibiotic residues in Brazilian UHT milk: a screening study
}

\author{
Resíduos de antibióticos em leite UHT \\ Gilberto Poggio FONSECA ${ }^{1}$, Adriano Gomes CRUZ ${ }^{1,2 *}$, Jose Assis Fonseca FARIA ${ }^{2}$, \\ Ramon SILVA ${ }^{1}$, Mirian Ribeiro Leite MOURA ${ }^{3}$, Lucia Maria Jager CARVALHO ${ }^{4}$
}

\begin{abstract}
The aim of this research was to carry out a screening study to check the incidence of antimicrobial residues in Brazilian UHT milk according to rapid yoghurt method. Of the 100 (100\%) samples analysed, 96 (96\%) showed no traces of antibiotic residues while 4 (4\%) indicated probable presence of antibiotic residues. The results suggest that the Brazilian Sanitary Surveillance Agency should apply continuous monitoring programs in order to obtain a safe product offering no health risks to consumers.

Keywords: antibiotic residue; UHT milk.
\end{abstract}

\section{Resumo}

O objetivo deste trabalho é realizar um estudo preliminar para verificar a presença de resíduos de antibióticos em leite UHT disponíveis no mercado brasileiro, utilizando o método rápido do iogurte. Das 100 (100\%) amostras analisadas, 96 (96\%) indicaram negativas, sugerindo ausência de resíduos de antibióticos, enquanto 4 (4\%) mostraram-se positivas. Os resultados sugerem a necessidade de contínuo monitoramento deste parâmetro por parte da Vigilância Sanitária com o objetivo de oferecer um produto seguro, sem riscos para saúde do consumidor.

Palavras-chave: leite UHT; resíduos de antibióticos.

\section{Introduction}

Due to its practicability and long shelf life, UHT milk has been widely consumed by the Brazilian population of all ages and socio-economic levels accounting for $74 \%$ of the fluid milk produced in 2003 (GURGEL, 2004). Considering sales outlets, an increase in the distribution to small retailers (bakeries, small grocery stores, greengrocers, and supermarkets) and an average sales growth per shop have been noticed, i.e., there has been more shops selling UHT milk with improved performance (ALVES, 2001). Consumers have showed different levels of tolerance towards antibiotic residues in milk, therefore, the implementation and monitoring of quality assurance programs in all stages of the milk handling and processing is crucial. A recent Brazilian legislation was introduced requiring a monthly analysis of the product for antibiotic residues by authorized laboratories, regardless of the frequency of analyses recommended by the internal quality program of the production unit (BRASIL, 2002).

Antibiotics are invariably administered to cattle to control infectious diseases, but their indiscriminate use, without adequate technical and veterinary control, can lead to a series of negative consequences at all levels of the dairy productive chain
(PORTUGAL et al., 2001). Toxic effects to human beings include hearing problems caused by streptomycin and allergy problems and anaphylactic shock caused by penicillin. In addition, it is widely recognised that the indiscriminate use of such substances promotes the development of resistant microorganisms hindering the antibiotic therapy. They are also heat resistant, so the temperatures used in the UHT process are ineffective in eliminating them (BRANCHER; FAGUNDES, 1998). In the fermented dairy products manufacturing, such as cheeses and yogurts, the presence of antibiotics and other antimicrobial agents can lead to the partial or total inhibition of the lactic bacteria resulting in products with compromised structural and sensory features (KECELLI; ROBINSON, 1997). In the typical case of stretched curd cheeses, such as provolone and mozzarella, the stretching process becomes impossible and the fermentation periods can be very extensive. When the cheese curd is cut, it results in higher losses of casein and fat to the whey leading to yield reduction. Cheese curing is also affected due to the lack of lactic bacteria in the desirable biochemical reactions, such as proteolysis (TRONCO, 2001). Sbampato et al. (2001) reported

1 Curso de Farmácia, Universidade Estácio de Sá - UNESA, CEP 202161-063, Rio de Janeiro - RJ, Brasil

${ }^{2}$ Departamento de Tecnologia de Alimentos, Faculdade de Engenharia de Alimentos, Universidade Estadual de Campinas - UNICAMP, CEP 13083-970, Campinas - SP, Brasil, E-mail: food@globo.com

${ }_{3}^{3}$ Departamento de Produtos Naturais e Alimentos, Faculdade de Farmácia, Universidade Federal do Rio de Janeiro - UFRJ, Cidade Universitária, CEP 21941-590, Rio de Janeiro - RJ, Brasil

${ }^{4}$ Departamento de Nutrição Básica e Experimental, Instituto de Nutrição, Universidade Federal do Rio de Janeiro - UFRJ, Cidade Universitária, CEP 21941-590, Rio de Janeiro, RJ - Brasil

${ }^{*}$ A quem a correspondência deve ser enviada 
inhibition of the lactic starter culture during yoghurt production and a delay in coagulation of cheese. Additionally, it was observed different behaviour at the reductase test in milk inoculated with increasing concentrations of penicillin, streptomycin, and tetracycline. The PAMVet - Brazilian Surveillance Program of Veterinary Residues Drug in Food of Animal Origin - monitored the occurrence of antimicrobial residues in UHT milk marketed in several Brazilian states from 2004 to 2005. The absence of $\beta$-lactams, tetracyclines, neomycin, and dihydrostreptomycin/ streptomycin was reported while 5.0\% of UHT samples presented clorofenicol (ANVISA, 2006).

Recently, Nero et al. (2007) investigated the presence of antibiotics in 210 raw milk samples collected in four different milk-producing areas in Brazil using the qualitative method. Antibiotic residues was detected in 24 samples (11.4\%), suggesting that, like in other countries, antibiotic may be an important chemical hazard in the milk produced in Brazil.

Considering the relevance of antibiotic residues in the dairy production chain and the limited number of studies on UHT milk published in Brazil, the objective of this study was to investigate the incidence of antibiotic residues in Brazilian UHT milk.

\section{Materials and methods}

100 UHT milk samples were collected according the sampling plan established by the Codex Alimentarius (1993). The samples were from 10 different commercial brands manufactured in industrial dairy units in several Brazilian States (Rio de Janeiro, Goiás, Minas Gerais, Rio Grande do Sul, and São Paulo). They were collected at random from retail establishments in the city of Rio de Janeiro.

The rapid yoghurt method, proposed by Yamani et al. (1999) and which is a practical economical test appropriate for industrial routine, was the method chosen to develop this study. Its principle is based on the inhibition of acid formation during fermentation by Streptococcus thermophilus and Lactobacillus delbrueckii ssp bulgaricus, microbial starter cultures typically used in yoghurt manufacture. The technique consists of initially heating of $10 \mathrm{~mL}$ of the sample up to $80^{\circ} \mathrm{C}$ for 5 minutes, cooling to $45^{\circ} \mathrm{C}$, and adding $1 \mathrm{~mL}$ of a previously prepared mixture [10 mL yoghurt (recent active culture) $+10 \mathrm{~mL}$ sterile milk or water $+20 \mathrm{~mL}$ bromocresol purple dye solution $(1 \mathrm{~g}$ to $300 \mathrm{~mL}$ distilled water)]. The inoculated milk sample was incubated at $45^{\circ} \mathrm{C}$ for 2 hours. During this period, the microorganisms were stimulated to grow reducing the $\mathrm{pH}$ of the mixture due to the production of acid and causing a change in the color of the dye from purple to yellow with the production of a homogeneous coagulum and normal fermentation indicating the absence of inhibitors. The test is considered positive, indicating the presence of antibiotics, if the color remains purple and it presents liquid consistency. During all the experiment, positive and negative controls were performed and remained available for a better interpretation of the results.

\section{Results and discussion}

Table 1 shows the level of antibiotic residues in Brazilian UHT milk. According to the methodology used in this study,
Table 1. Level of antibiotic residues in Brazilian UHT milk.

\begin{tabular}{lcc}
\hline \multicolumn{1}{c}{ Place } & \multicolumn{2}{c}{ Sample } \\
\cline { 2 - 3 } & Positive (\%) & Negative (\%) \\
\hline São Paulo & 0 & 20 \\
Rio de Janeiro & 0 & 20 \\
Minas Gerais & 4 & 16 \\
Rio Grande do Sul & 0 & 20 \\
Goiás & 0 & 20 \\
Total & 4 & 96 \\
\hline
\end{tabular}

of the 100 (100\%) samples analysed 96 (96\%) were negative suggesting the absence of antibiotic residues while 4 (4\%) were positive. All positive samples were from the same commercial brand coming from an industrial unit in the State of Minas Gerais, probably reflecting regional farmers' malpractice. The results suggest unsatisfactory quality of the UHT milk produced regarding this parameter and inadequate milking practices by farmers. Therefore, continuous surveillance to enforce the current Brazilian legislation is needed independent of the frequency of analyses recommended by the internal quality program of the dairy production unit (BRASIL, 2002).

The results found in this study show higher levels than those from other countries although a different methodology was used. Leme et al. (2004) investigated the presence of antibiotic residues in UHT milk marketed in the city of São Paulo, Brazil, relating their presence in $0.6 \%$ of the samples. Wit et al. (1996) observed the presence of antibiotics in UHT milk produced in Holland stating that $100 \%$ of the samples were below the maximum residue limit. Baynes et al. (1999) found total absence in similar research in Costa Rica. However, Santos and Rodrigues (2003) also using the rapid yoghurt method, reported $37.5 \%$ of positive samples of UHT milk marketed in Uberlândia, State of Minas Gerais, Brazil.

Despite the fact that the findings of this research are qualitative, they are relevant and show that this methodology might be used for screening tests in internal quality programs of dairy industries since it is easy, quick, and inexpensive. Only the positive samples found as a result of this study were sent for further testing to obtain more specific identification and quantification of waste and for retesting confirm the positive results, which represents significant cost savings.

Competent authorities must apply continuous monitoring programs in order to obtain a safe product offering no health risks to Brazilian consumers. In addition, more research should be carried out on this subject in the several different regions of Brazil in order to obtain an accurate dimension of the problem and implement effective corrective actions.

\section{Conclusion}

Although the results are reported in a qualitative way, the rapid yoghurt method proposed can be used to internal screening tests in internal quality programs of dairy industries as a previous test to detect antibiotic residues in milk. 


\section{References}

AGENCIA NACIONAL DE VIGILÂNCIA SANITÁRIA - ANVISA. Programa de Análise de Resíduos de Medicamentos Veterinários em Alimentos de Origem Animal (PAMVet). Relatório 2004/2005. Monitoramento de Resíduos em Leite Exposto ao Consumo. Brasilia, 2006. 45p.

ALVES, D. R. The role of UHT milk in the growth of the Brazilian milk market. Australian Journal of Dairy Technology, v. 56, n. 2, p. 32, 2001.

BAYNES, R.E. et al. A preliminar survey of antibiotic residues and viable bacteria in milk from three Caribebean basic countries. Journal of Food Protection, v. 62, n. 2, p.177-180, 1999.

BRANCHER, C. C.; FAGUNDES, C. M. Adaptation of Redutase Method to detect antibiotic residues in milk. Brazilian Journal of Agroscience, v. 2, n.1, p. 80-84,1998

BRASIL. Ministério da Agricultura, Pecuária e Abastecimento. Instrução Normativa n. 51, de 18 de setembro de 2002. Disponível em: http:// www.agricultura.gov.br. Acesso em: Maio 2007.

Codex Alimentarius. Residuos de medicamentos veterinarios en los alimentos. 2 ed. Roma, Italy: Food and Agriculture and Organization, 1993.

GURGEL, A. Em busca do crescimento sustentado. Indústria de Laticínios, n. 9, p. 50-55, 2004.

KECELLI, T.; ROBINSON, R. K. Dairy products- the real risk. Dairy Industries International, v. 62, n. 1, p. 29-33, 1997.
LEME, F. B. P. et al. Prevalence of antimicrobial drugs in samples of different milks marketed in São Paulo, Brazil. In: BRAZILIAN CONGRESS MILK QUALITY, 1, 2004. Proceedings... Passo Fundo: Brazilian Council Milk Quality, 2004. (CD - ROM).

NERO, L. M. et al. Antimicrobial residues in raw milk from four Brazilian milk-producing regions. Ciência e Tecnologia de Alimentos, v. 27, n. 2, p. 391-393, 2007.

PORTUGAL, J. A. B. et al. Quality of milk and antibiotic residues. Revista do Instituto de Laticínios Cândido Tostes, v. 56, n. 309, p. 9-14, 2001

SANTOS, A. F. R.; RODRIGUES, M. A. M. Antimicrobial Residues in UHT milk. Higiene Alimentar, v. 7, n. supl., p. 174-175, 2003.

SBAMPATO, C. G.; ABREU, L. R.; MENDONÇA, A. T. Technological Aspects of yogurt and cheese processing using milk with antibiotic residues. Revista do Instituto de Laticínios Candido Tostes, v. 54, n. 313, p. 3-19, 2001.

TRONCO, V. M. Qualidade na Inspeção do Leite. Rio Grande do Sul: Editora UFSM, 2001. 234 p.

WIT, B. et al. Dectection of antibiotic substances in milk using capacitance measurement. Netherlands Milk Dairy Journal, v. 50, n. 2, p. 573-580, 1996.

YAMANI, M. I. et al. A simple test for detection of antibiotics and other chemical residues in ex-farm milk. Food Control, v. 10, n. 1, p. 35-39, 1999. 